\title{
SYSTEMS AND POLITICAL DEVELOPMENT IN MALAYSIA
}

\author{
O. Argo Victoria, Fadly Ameer \\ argovictoriaupin@gmail.com, fadzz_93@yahoo.com \\ (Internasional Islamic University Malaysia)
}

\begin{abstract}
Abstrak
Malaysia is a country in Southeast Asia with an area of $329758 \mathrm{~km} 2$ and a population in 2007 amounted to 27.17 million. Of the total population in $2007,60 \%$ are ethnic Malay "Bumiputerd", 26\% ethnic Chinese, 8\% Indians, 5\% other ethnic Bumiputera, and 1\% other ethnic groups such as Arabic, Sinhalese, Eurasian and Europe. ${ }^{1}$ Under the constitution, Malays are Malaysian citizens who practice a traditional Malay, Melayu Language, and Muslim. Approximately $25 \%$ of the Malaysian population is Chinese, and $7 \%$ is made up of India. Almost $85 \%$ of the races Indians in Malaysia are Tamil community. More than half the population of Sarawak and Sabah $66 \%$ of the population consists of non-Malay indigenous people. The entry of another race to some extent reduce the percentage of indigenous population in the two states. In addition, Malaysia also has a population that comes out of Europe and the Middle East. Malaysia's population density is not distributed evenly, with 17 million of the 25 million people living in Peninsula Malaysia.
\end{abstract}

Keywords: Malaysia, Politic, Constitutional.

\section{A. INTRODUCTION}

Malaysia is a constitutional monarchy that parliamentary democracies, and the prime minister and the prime minister elected by the people through elections that take place regularly every five years. YDPA currently the 12th since Malaysia's independence on August 31, 1957.

When a newly independent Malaysia consists of 11 states part 1 and called Persekutuan Tanah Melayu (Federation of Malaya). Then in 1963 the state of Sarawak and Sabah joined the Federation of Malaysia. Malaysia is known as a multi-ethnic country and rich cultural treasure that has approximately 30 groups ethnic. 2 Less than 8 percent of the population were below the poverty line before the economic crisis of 1997; literacy rate of

\footnotetext{
${ }^{1}$ Barbara Watson Andaya and Leonard Andaya, 1983, History of Malaysia, Petaling Jaya: Macmillan Publishers, p. 6-7
} 
over 85 percent and life expectancy of their peoples on par with developed countries. Malaysia has a bicameral parliamentary system, the People's Council and the Council of State. Members of the Board shall be elected through elections, while the members of the Council of State appointed by the states or directly appointed by YDPA based on input from the prime minister².

Malayan Union was introduced by the British Labor Party a few months after the British reoccupied Tanah Melayu. It said the implementation of the Malayan Union in April 1946 at the Tanah Melayu has aroused the spirit of nationalism locals especially the Malays.

They feel the customs and traditions that brought the Malayan Union is contrary to the nation, Malaysia, Malayan Union drastically changed the standard of Malay lands from foreign lands British protectorate to a colony directly Britain, removing the privileges of the Malays as Bumiputera by introducing the concept of democracy 'jus soli 'namely the citizenship granted to all foreigners who are born in the Malay and those aged 18 years or over and have lived for 10 of the 15 years prior to 15 February 1942, as well as removing the sovereignty of the Malay kings.

To achieve the condition of society who live healthy and prosperous in the future, ${ }^{3}$ Malays felt threatened by them migrants. China and India are the people in the country wilt very easily. This situation raises the most important chaos Malays lose their political power ${ }^{4}$.

This has led to disagreement among the officials and the nobility of Malay as Dato Onn Jaafar, Dr Burhanuddin Helmi and some educated Malays. They felt humiliated by the British attitude arrogant and act as they pleased in reforms. Conflicts intensified after the role of the Malay newspapers such as "Utusan Melayu", the Assembly and the State News criticize and explain the ugliness Malayan Union ${ }^{5}$. This condition is further aggravated by the recognition of British officials who have retired like Frank Swettanham, George Maxwell, and Winstedt through their writing in the British newspapers that expressed their resentment against British injustice ways make the constitutional amendment. But the Malays against a more organized

\footnotetext{
${ }^{2}$ Ibid. p.10

${ }^{3}$ Muallim, M. H., Gunarto, G., \& Mashdurohatun, A. (2017). RECONSTRUCTION OF THE WASTE MANAGEMENT LAW BASED ON WELFARE VALUE. The 2nd Proceeding "Indonesia Clean of Corruption in 2020". P.616.

${ }^{4}$ http://www.adb.org/Documents/Fact Sheets/MAL.pdf, accessed on 06 September 2018.

5 Fadilah Zaini and Thukiman Kassim, 2008, Ethnic Relations in Malaysia, Johor Bharu: Universiti Teknologi Malaysia, p.57
} 
and collective, including the form of a protest demonstration in Kelantan by the Association of Malay 1945 and 1946 in Kedah and Johor.

In addition the meeting held on 11 March 1946 that the first Malay Congress combine 41 Malay organizations included PKMM and agreed to form the whole Tanah Melayu in Malay Congress. He aims to fight against the Malayan Union and to unite the Malays in a strong body.

At that time, Congress has no plans of social and economic ripe, otherwise just want to restore the rule of Melayu's kings and Malay rights as an indigenous people. It has also been stated that the agreement is not valid Michael is excluded because the officials wither and society. Through this Congress, has given birth to Malays National Organization (UMNO) on 11 May 1946, to maintain the interests of the Malays. Where Dato Onn Jaafar as the main leader and first. May 1946 was the largest protest of the Malays against England. Finally made constitutional changes that gave birth to the Federation of Malay Land in $1948^{6}$.

\section{B. DISCUSSION}

\section{Party In Malaysia}

\section{a. Malay Party (UMNO) Of 1946}

The birth of UMNO is the result of the merging of Malay organizations with various schools of philosophy and opinion but agreed to take collective action to advance and fight invaders Malay people. People are united to form the Malay UMNO as a bulwark against the threat hah-rights of the Malays By Malayan Union in 1946. The establishment of UMNO on May 11, 1946, by Dato 'Onn bin Ja'far as the first leader who can be regarded as movement Malays in Malaya to prevent them from sinking under the political and economic developments were so swift and favorable other clans are more advanced.

The first is the UMNO struggle against the Malayan Union. Through the newspapers and for the expected voice Malay people can be known by the Malayan Union. UMNO leaders managed to persuade the Sultan of Malay to not attend the

\footnotetext{
${ }^{6}$ Ibid.
} 
appointment ceremony of the Governor of the Malayan Union, namely Edward Gent, here clearly shows the lack indigenous people against the Malayan Union.

b. Malaysia Islamic Party (PAS) 1951

The emergence of PAS in the political history of land Malaysia started since August 23, 1951 when the scholars who met in Kuala Lumpur agreed to establish a union called the Union of Malaysian Ulama. This unity name was later changed to the Union of Islamic Malaysia (PAS) 24 November 1951, at a conference of scholars Malaya. That bit of the early history of PAS established by scholars who later evolved into a political-propaganda organization are important in Malaya country.

The emergence of PAS is linked from the influences that occur in some of the early Islamic movements like the Muslim Brotherhood in Egypt, Masjumi in Indonesia and the Jamaat Islami in Pakistan. All three of these influences have entered Tanah Melayu through the scholars who studied in Egypt, Mecca, India and Indonesia?.

Consciousness beginning to appear are the scholars or Muslims require an organization or agency ${ }^{8}$ that can represent them in all aspects of life, especially under conditions of Tanah Melayu is being colonized by the British. The existence of this understanding then generate Supreme Council of Religious Malaya (EYES) in 1947 followed by Hizbul Muslimin in 1948.

PAS into an Islamic political organization fighting for independence through democratic foundations. The scholars reject the forms of struggle are founded on an ideology of human creation that was brought in by the invaders. Since then, PAS emerged as an Islamic political organization fighting for independence of the country, then join the contest elections. PAS also uses various channels to convey his message messages including forming some political cooperation with nonMuslims since 1953. Under the leadership of Tuan Guru Haji Ahmad Fuad Hassan and Dr Haji Abbas Alias, PAS talking about independence could be enforced Islamic

\footnotetext{
${ }^{7}$ Adam, Ramlah, 2000, Dr Burhanuddin Al-Hemyi: A Political Crisis, Kuala Lumpur: Dewan Bahasa Dan Pustaka, Ministry of Education Malaysia, p. 22

${ }^{8}$ Gunarto, 2018, Fair Consumer Protection, Balanced And Proportional In A Fixed E-Commerce Agreement Based On Justice Value, Scholars Journal Of Arts, Humanities And Social Sciences, India, p.63
} 
law. PAS refused citizenship jus soli adverse natives and PAS urged that Islam be the basis of an independent state.

c. Democratic Action Party (DAP) 1965

The party was officially registered six months later on March 18, 1966 as a social democratic party. DAP is more favored by the Chinese and received a small part of the India. DAP is controlled by the Chinese and is well received by the Chinese in the cities. DAP famous concept of "Malaysian Malaysia" (Malaysian for all the people of Malaysia). The party is committed to the struggle for a Malaysian Malaysia which is free, is democratic socialism, based on the principles of human rights, equality, social and economic justice, and democratic institutions based Parliament. Dap no winners among the major world powers influence whether Western or Eastern bloc block ${ }^{9}$.

\section{Federated Malay Land 1948}

The results of the consultation working committee comprising representatives of the government, sultans and UMNO succeeded in forming a new constitution, namely the Federation of Malay Land 1948 provisions to be tightened Malay citizenship rights and privileges of the Malays as the indigenous people are recognized. In general, this federal provide opportunities for local children to master the country through positions such as Minister, Secretary Local Government and others, to ensure that they can lead independent state. From the geopolitical aspects of the country for the first time all Tanah Melayu placed in one administration. But in the fine anyway UK has managed to open a populist on the other clans ${ }^{10}$.

The ceremony that ended British colonial history for hundreds of years in Singapore, Sabah and Sarawak have been signed in five copies by representatives of the governments involved. The British government has been represented by Prime Minister Harold Macmillan, Mr Ducan Sandys and Lord Landsdowne. Tanah Melayu Federation government also has been represented by Prime Minister Tunku Abdul

\footnotetext{
${ }^{9}$ Purcell, Victor, 1967, The Chinese in Tanah Melayu, Oxford: Oxford University Press, p.8

${ }^{10}$ Bustamam, Ahmad, 1972, Leads The Way Summit, Kuala Lumpur: Pustaka Pagi Publishing, p. 19
} 
Rahman, Tun Abdul Razak, Mr. Tan Siew Sin, Datuk VT Sambanthan, Datuk Ong Yoke Lin and Dr. Lim Swee Aun. Sabah was represented by Datuk Mustapha bin Datu Harun, Mr. Donald A. Stephen, WKH Mr Jones, Mr Khoo Siak Chiew, Mr WS Holley and Mr GD Sundang. Representatives from Sarawak land also comprised of $\mathrm{PEH} M r \mathrm{Pike}^{11}$, Tomonggong Jugah, Bandar Datuk Abang Haji Mustapha, Mr Ling Beng Siew and Datuk Abang Haji Openg.

\section{Singapore Split From Malaysia}

In 1965, Singapore separated from the Federation of Malaysia. Declaration on the separation was made by YTM Tunku Abdul Rahman Putra, the Malaysian Prime Minister in the "Dewan Rakyat". Measures separation of Singapore from Malaysia considered the best because this is the only way out for the sake of unity and avoid a clash between residents of Malaysia and Singapore, and impending economic stability and to avoid political conflict between the Government of Malaysia which is controlled by the Alliance Party with the People's Action Party Singapore's ruling. This separation action performed after agreement is reached between the two sides.

YTM Tunku Abdul Rahman also said that other causes of this separation because of the attitude half the political leaders of Singapore who championed the concept of 'Malaysian Malaysia', as well as denying the existence of institutions Malay Sultanate, against the rights privileges of the Malays and natives as well as the absence of the equation opinions in increasing and advancing the fundamentals of trade, taxation and industrial division. But the separation of Singapore from Malaysia was made with the understanding that Malaysia and Singapore would continue to cooperate in the fields of defense, business and trade ${ }^{12}$.

One agreement has been drawn up and signed by both parties. In a separation agreement the two countries Malaysia was represented by YTM Tunku Abdul Rahman Putra, Tun Abdul Razak, Dato 'Dr. Ismail b. Abdurrahman, Tan Siew Sin and Dato 'VT

${ }^{11}$ Ibid. p. 21

${ }^{12}$ Anis Mashdurohatun, 2017, Hukum Kontrak, Ekonomi Syariah Dan Etika, Undip Press, Semarang, p.26 
Sambanthan. While Singapore is represented by Eneik Lee Kuan Yew, Dr. Toh Chin Chye, Dr. Goh Keng Swee, Mr Sa Rajaratnam and Eneik Othman Wok.

The separation of Singapore from Malaysia automatically make the citizens of Singapore will no longer be a citizen of Malaysia. consequently 2 Senators and 15 members of Parliament of Singapore is no longer a member of the Malaysian Parliament. In addition, all persons, including members of the armed forces, police, courts and others who used the staff of the Government of Malaysia, starting today they returned to staff the Government of Singapore. But the Malaysian government will continue to adhere to the treaties on water supplies that have been made between the Government of Singapore and the Kingdom of Johor. Although it has been split, the Malaysian Government still recognizes Singapore as an independent and sovereign state and will always work and befriend him.

\section{Political Hegemony Malaysia}

It is customary for the king or local government requires people to be loyal ${ }^{13}$ to them. This means that the king can not be contradicted, or confronted because of what it considered an act against tradition. The result appears a doctrine that people are afraid and and always humble himself before the king. With this kind of power the king more easily expand its power in various fields such as business sector, etc. The political power that gives them opportunity to be involved in the economic sector and mastery in the economic sector as well strengthen their political position ${ }^{14}$.

The king is not only demanded by the respect but they have used their position to reap the opportunities of wealth in the economic sector and other sectors. Try traditional elements applied in practice democracy in Malaysia. But there is no doubt that democracy is applied mixed with traditional background of these communities as well as handle customs and traditions religion becomes the main core.

\footnotetext{
${ }^{13}$ Sri Endah Wahyuningsih, 2014, Restorative Justice System-Di Tingkat Penyidikan Tindak Pidana Lalu Lintas, Tunas Puitika Publishing, Brebes, p.31

${ }^{14}$ Jaafar, Kamaruddin, 1980, Dr. Burhanuddin al-Helmy: Islam and Malay Ethnicity, Kuala Lumpur: Publisher Your Foundation, p. 64
} 
Unwittingly, the government has sought to gather strength and be in a safe position and successfully steered views of the community to accept their dominant position without any problems. Very clear political hegemony in the political system of government of Malaysia through the Barisan Nasional (BN) were in favor by UMNO as the main force of elite controls the government of Malaysia. BN containing the Malay elite no longer pay attention to the NGO, ranks of the opposition, the media and the judiciary more to fight the voices of modern democracy.

In relation to that, all forms of organizations, police, army, judiciary, etc. that exist in government used entirely by $\mathrm{BN}$ before and after the election to strengthen and maintain the interests of the upper classes. In addition, legislation such as the Official Secrets Act (OSA), Homeland Security Act (ISA), Printing Act used by the government to control and punish the Malaysian political opponents of the government.

The main political party of Malaysia, Pertubuhan Kebangsaan Melayu Bersatu (UMNO), has held sway along party - the other party since independence in 1957. UMNO Malaysia bigger when it becomes Rows of National BN. The National Front has three important components - UMNO, MCA (Malaysian Chinese Association) and MIC (Malaysian Indian Congress) ${ }^{15}$.

It turned out that the BN especially the Malay elite has managed to dominate the system of government in Malaysia so that the Malaysian electoral system, their victory in general has been guaranteed selection. For example, UMNO is the dominant party which is represented and supported by the Malay elites designated to dominate important state institutions like the police, the army, the courts, the legislature and so on. With the dominance of the Malay elite, enabling them to control the movement of government systems to ensure that systems are formed according to their political culture trends.

On July 27, 1955, run the first general election in history after decades of occupation. Parties are the main competing Engagement Party, Countrymen PAS, State Party, the Labor Party and the Progressive People's Party. These elections have been

${ }^{15}$ Malaysia Kita: Guide and Reference To An Empire, 2003, Petaling Jaya: International Law Book Services, p. 16-17 
held with the cooperation of the British colonial. Engagement Party has placed candidates for 52 seats overall. In those elections Engagement Party won 51 of the 52 seats contested.

Engagement Party victory UMNO-MCA has proven leadership and cooperation between the various people who helped fight for a comprehensive manifesto to the people of Tanah Melayu. Basics of Engagement set by the wise this is a step in which the hegemony of the West have passed unnoticed by the local community. Basics championed Engagement UMNO considered very 'generous' to help the local community. Behind the nature of 'generous', they expect support and loyalty of the people to ensure the success of the policy ${ }^{16}$.

At the time of the last election, the elections held in the year 2004 was an era $1964,1974,1978,1982,1986,1995$ and glories of Barisan Nasional fully supported by UMNO. In the 1964 elections (elections 3rd) won the National ranks 74 of 104 parliament seats, or 85 percent in 1964. In the 1974 general election, BN got 87 percent is a huge win.

Followed the elections in 1978 with the victory of BN as many as 130 seats of the 154 seats in the "Dewan Rakyat"that is less than the achievement of five seats in the elections of 1974. In the elections to the 6th (1982), BN got the win as many as 132 seats out of 154 seats in People's Council and is 85.7 percent of the seats, and is the second highest achievement since independence when.

While in the general election while the 7th (1986) BN got the win 148 seats out of 177 seats in the House of the People (83.6\%) there was a slight decrease of 2.4 percent compared to last choice. However, BN managed to retain its majority in parliament and seeks to maintain his grip on the post of prime minister and form a government. On election 9th 1995, BN retain a majority in parliament by winning 162 seats out of 192 seats in the "Dewan Rakyat", which is 84.4 per cent and an increase of 19.6 percent compared to the last election. Election 2004 is a general election to the 11th, BN achieve noise rise as much as 63.9. BN won 198 seats out of 219 seats in the assembly of the people. This is a great winning since the 1978 election.

\footnotetext{
${ }^{16}$ Mohamad Mahathir, 1995, The Early Years 1947-1972, Kuala Lumpur: News Publishing Sdn Bhd., p. 32
} 
UMNO is seen by the Malays as a vehicle and container fate of the Malay struggle. In addition, the BN and UMNO as a milestone in the government have the political power in governing the country. The Malays were too dependent on UMNO to defend their fate. If they take the position of Malay political parties who were not involved in the government does not have political power domination.

The position of hegemony BN win big in the elections (in 1964,1974,1978, 1982, 1986, 1995 and 2004) has ensured BN obtain the loyalty and support that is second to none of the people under their rule. The government does not forget to give the post to their loyal supporters with various forms of benefits such as positions in the government, the name and rank. Reversionary who oppose the Prime Minister or the government leaders will be labeled as mutineers, deserters, opposition, antigovernment, traitors and various other negative degree.

\section{Nationalist Party And Islam Malaysia}

In the context of Malaysia, Malays and Islam are often seen as one component of which is very difficult to separate. When certain individuals belonging to ethnic Malays then directly be identified Muslim. In more extreme conditions, in addition to ethnic Malays who embraced Islam would say "Come in Malay" and will leave the identity of ethnic origin. This view was reinforced by the Federation Constitution that says, "Malay means someone who embraced Islam, Fluency speak Malay, according to Malay custom".

In politics Malaysia, Malays and Islam, often paired together. He was used as the party's ideology. Not infrequently some people considered that it was wrong because generally there is a clear difference between the Malays and Islam. Malay ethnic and ethnic-based struggle branded as nationalism ${ }^{17}$.

\section{Malaysia Economic Policy}

After the racial riots of May 13, 1969, the controversial New Economic Policy was issued by the Prime Minister Tun Abdul Razak. Malaysia's new economic policy of

${ }^{17}$ Ibid. 
maintaining the balance of ethno-politics, and developed a unique rule combining economic growth and political rule that favors Bumiputera (a group of ethnic Malays and indigenous people) and Malaysian citizens who embraced Islam.

Between the 1980s and the early 1990s, Malaysia experienced rapid economic growth under the leadership of Dr. Mahathir bin Mohamad, Malaysia's fourth prime minister. The period saw a shift from an economy based on agriculture into manufacturing and industry in the field of computers and consumer electronics.

In the late 1990s, Malaysia was shaken by the Asian financial crisis. Opposition to some aspects of the system that was put down by the government. Opposition socialists and reformists to the party advocating the creation of an Islamic state. In 2003, Dr. Mahathir, the longest-serving prime minister in Malaysia, resigned and handed over the post to Abdullah Ahmad Badawi. The new government advocated a moderate view of Islamic state defined by Islam Hadhari.

Malaysia is a simple income country, transformed from a country producing raw materials such as latex, lead ore and so on. In 1971, it became a multi-sectoral country through the New Economic Policy. Basically, the growth of Malaysia's exportdependent electronic materials such as computer chips and so forth. As a result, Malaysia feel great pressure during the economic crisis in 1998 and the slump in the information technology sector in 2001 . KDNK in 2001 only increased by $0.3 \%$ due to a reduction of $11 \%$ in export numbers but large fiscal stimulus package has reduced the impact of ,

Malaysia has a stable macroeconomic elements (where the inflation rate and the unemployment rate remained below 3\%), foreign exchange deposits healthy, and low foreign debt. This enables Malaysia to not experience the same crisis as the Asian financial crisis in 1997. However, the long-term outlook seems less well due to the lack of change in the legal entity sector, especially sectors that deal with corporate debt is high and competitive. In addition to latex and oil palm which many in Peninsular Malaysia, Sabah and Sarawak are also rich in natural resources such as wood logs, petroleum and natural gas ${ }^{18}$.

${ }^{18}$ Adam, Ramlah,op.cit, p.87 


\section{Women in World Politics Malaysia}

In 2002, the Malaysian state has three figures of women holding ministerial posts: Minister of Women's Affairs and Family Development, Minister of International Trade and Industry, and the Minister of Welfare and National Unity. In addition, many of the women who hold important positions in government, including deputy ministers, political secretaries, diplomats, senior government officials, members assembly states, and the senators in the State Council.

However, the presence of women in decision making process in Malaysia is still far from enough. Many women leaders who discuss gender equality in this context. At this time, women are still lacking representation in political institutions in Malaysia.

According Rashila and Saliha are at least five common factors that become obstacles for active participation of Malaysian women in politics. They classify these factors as societal discrimination against women's role in public life, time constraints caused by the demands of career and home, the arguments of cultural and religious states that the place of women is in the home, the structural constraints within each political party which does not allow women to go beyond a certain level of political career, as well as a lack of support resources, either in the form of organizational support, influence and funds.

Contrary to common misconceptions, in fact there is an understanding of the concept of Islam that allows people to appreciate the possibilities towards "liberation of women" based on the content of the teachings of the religion. In many cases, religion has been to empower and enable women achieve and realize their potential and capabilities equal to men. The experience of women in Malaysia at the end of the turn of the last century proved this.

\section{Constraints / Problems Faced Woman Malaysia in Parliament}

The many problems faced by women who entered politics in Malaysia and made many of them afraid to involve themselves in politics ${ }^{19}$.

a. Double burden

${ }^{19}$ Ibid. 
Women themselves are much less strict and often forced to bear a double burden, which must be very clever to balance the household chores with the problems of career, so many of them are entangled great difficulty, unless they are really strong and tough reach ambition.

b. Political parties

Characters and characteristics of political parties that many pose an obstacle for women's involvement in politics. In general it is the ruling parties and established will maintain a conservative attitude and did not want to see and adapt to current radical changes in society. Only political parties or opposition alternative dynamic that would provide opportunities and greater opportunities to women. Also, many political parties that lack the resources to conduct training and education, even for the members of her, because of the pressures imposed by the authorities.

c. Hostile environment towards women

It is sad that many MPs and council representatives of the countries that are still part of women experiencing sexual harassment, either in the form irrelevant comments as well as a burst of offensive in the sessions of Parliament and meetings of the representative councils. Another factor that causes women are reluctant to plunge into the world of politics is their mistaken assumption that politics is a world of men, besides they are also often scared by the thick hypocrisy and dirty games typical of the political world.

\section{Malaysian Politics}

In simple terms we can explain a little about Malaysia's political system, the country is a constitutional monarchy. Malaysia is headed by a king who was commonly known as the Yang di-Pertuan Agung elected by and from 9 sultan state-led Malaysian state sultan to serve for five years in rotation. This system is based on the Westminster because Malaysia is a former British Colony. More power is held by the executive branch than the legislative. Regular elections are held every five years ${ }^{20}$.

\footnotetext{
${ }^{20}$ Mohamad Mahathir, op.cit., p.62
} 
Politics of Malaysia takes place in the framework of a federal representative democratic constitutional monarchy, in which the Yang di-Pertuan Agong is head of state and the Prime Minister of Malaysia is the head of government. Executive power is exercised by the federal government and the 13 state governments. Federal legislative power is vested in the federal parliament and the 13 state assemblies. The judiciary is independent of the executive and the legislature, though the executive maintains a certain level of influence in the appointment of judges to the courts ${ }^{21}$.

The Constitution of Malaysia is codified and the system of government is based on the Westminster system. The hierarchy of authority in Malaysia, in accordance to the Federal Constitution, stipulates the three branches (administrative components) of the Malaysian government as consisting of the Executive, Judiciary and Legislative branch. Whereas, the Parliament consists of the Dewan Negara (Upper House / House of Senate) and Dewan Rakyat (Lower House / House of Representatives).

Malaysia has had a multi-party system since the first direct election of the Federal Legislative Council of the Malaya in 1955 on a first-past-the-post basis. The ruling party was the Alliance Party (Malay: Parti Perikatan) coalition and from 1973 onwards, its successor, the Barisan Nasional (National Front) coalition. Since the 14th general election that was held on 9 May 2018, the Pakatan Harapan coalition was elected as the country's new federal government. The Pakatan Harapan coalition currently consists of (PKR) People's Justice Party (Malaysia), Democratic Action Party (Malaysia), National Trust Party (Malaysia), Malaysian United Indigenous Party, and the Sabah Heritage Party.The opposition are made up of one of the world's longest serving government Barisan Nasional, the Pan-Malaysian Islamic Party (PAS), and other smaller parties.

Although Malaysian politics has been relatively stable, critics allege that "the government, ruling party, and administration are intertwined with few countervailing forces." However, since the 8 March 2008 General Election, the media's coverage on the country's politics has noticeably increased.

${ }^{21}$ https://en.m.wikipedia.org/wiki/Politics_of_Malaysia 
Executive power is set by the cabinet headed by the Prime Minister. Malaysian constitution, the prime minister must be a member of the People's Council, which in the opinion of the Yang di-Pertuan Agung, a majority in parliament. The cabinet is a member of parliament elected from the "Dewan Rakyat"or "Dewan Negara".

\section{CONCLUTION}

Parliament consists of the People's Council and the Council of State. The State Council has 70 senators (call given to members of the State Council). Election of the members can be divided in two:

1. 26 members elected by the Council of State as a representative Invitation 13 states (each state is represented by two members).

2. 44 members are appointed by the Yang di-Pertuan Agong on the advice of the Prime Minister, including two members of Wilayah Persekutuan Kuala Lumpur, and one member each from Wilayah Persekutuan Labuan and Putrajaya. People's Council has 222 members, and each member represents a constituency. They were selected on the basis of support of many parties through the election. Every member of the People's Council hold office for five years, after which new elections will be held. Judicial power is shared between the government and the state government alliance. Political power in Malaysia is very important to fight for the issues and rights. The power thus plays a very important role in making a change.

\section{BIBLIOGRAPHY}

Adam, Ramlah, 2000, Dr Burhanuddin Al-Hemyi: A Political Crisis, Kuala Lumpur: Dewan Bahasa Dan Pustaka, Ministry of Education Malaysia

Anis Mashdurohatun, 2017, Hukum Kontrak, Ekonomi Syariah Dan Etika, Undip Press, Semarang.

Barbara Watson Andaya and Leonard Andaya, 1983, History of Malaysia, Petaling Jaya: Macmillan Publishers

Bustamam, Ahmad, 1972, Leads The Way Summit, Kuala Lumpur: Pustaka Pagi Publishing 
Fadilah Zaini and Thukiman Kassim, 2008, Ethnic Relations in Malaysia, Johor Bharu: Universiti Teknologi Malaysia

Gunarto, 2018, Fair Consumer Protection, Balanced And Proportional In A Fixed ECommerce Agreement Based On Justice Value, Scholars Journal Of Arts, Humanities And Social Sciences, India.

Jaafar, Kamaruddin, 1980, Dr. Burhanuddin al-Helmy: Islam and Malay Ethnicity, Kuala Lumpur: Publisher Your Foundation

Malaysia Kita: Guide and Reference To An Empire, 2003, Petaling Jaya: International Law Book Services

Mohamad Mahathir, 1995, The Early Years 1947-1972, Kuala Lumpur: News Publishing Sdn Bhd.

Muallim, M. H., Gunarto, G., \& Mashdurohatun, A. (2017). RECONSTRUCTION OF THE WASTE MANAGEMENT LAW BASED ON WELFARE VALUE. The 2nd Proceeding "Indonesia Clean of Corruption in 2020".

Purcell, Victor, 1967, The Chinese in Tanah Melayu, Oxford: Oxford University Press

Sri Endah Wahyuningsih, 2014, Restorative Justice System-Di Tingkat Penyidikan Tindak Pidana Lalu Lintas, Tunas Puitika Publishing, Brebes.

http://www.adb.org/Documents/Fact Sheets/MAL.pdf 